\title{
Spirulina lipopolysaccharides inhibit tumor growth in a Toll-like receptor 4-dependent manner by altering the cytokine milieu from interleukin-17/interleukin-23 to interferon- $\gamma$
}

\author{
HIROMI OKUYAMA ${ }^{1}$, AKIRA TOMINAGA ${ }^{2}$, SATOSHI FUKUOKA ${ }^{3}$, \\ TAKAHIRO TAGUCHI $^{2}$, YUTAKA KUSUMOTO ${ }^{1}$ and SHIRO ONO ${ }^{1}$ \\ ${ }^{1}$ Laboratory of Immunology, Faculty of Pharmacy, Osaka Ohtani University, Tondabayashi, \\ Osaka 584-8540; ${ }^{2}$ Laboratory of Human Health and Medical Science, Graduate School of Kuroshio Science, \\ and Department of Molecular Biology and Cellular Biology, Kochi Medical School, Kochi University, \\ Nankoku, Kochi 783-8505; ${ }^{3}$ Health Technology Research Center, National Institute of Advanced Industrial \\ Science and Technology (AIST), Takamatsu, Kagawa 761-0395, Japan
}

Received August 1, 2016; Accepted December 14, 2016

DOI: $10.3892 /$ or.2017.5346

\begin{abstract}
Th17 cells and the cytokine they produce, interleukin (IL)-17, play an important role in tumor progression in humans and in mice. IL-6 and IL-23 are critical cytokines for the differentiation and propagation of Th17 cells, respectively. Bacterial lipopolysaccharides (LPS) are known to stimulate immune cells to produce such inflammatory cytokines. Contrary to Escherichia coli (E. coli) LPS, LPS from Spirulina has low toxicity and barely induces in vivo production of IL-6 and IL-23 in mice. We examined the antitumor effects of Spirulina LPS compared to E. coli LPS in an MH134 hepatoma model. Administration of Spirulina LPS suppressed tumor growth in $\mathrm{C} 3 \mathrm{H} / \mathrm{HeN}$ mice, but not in Tolllike receptor 4 (TLR4)-mutant $\mathrm{C} 3 \mathrm{H} / \mathrm{HeJ}$ mice, by reducing serum levels of IL-17 and IL-23, while increasing interferon (IFN) $-\gamma$ levels. The antitumor activity and IFN- $\gamma$ production were mediated by $\mathrm{T}$ cells. Moreover, in vitro experiments showed that Spirulina LPS impaired the antigen-presenting function that supports the generation of IL-17-producing cells in a toll-like receptor (TLR)4-dependent manner. Of note, injection of anti-IL-17 antibody in tumor-bearing $\mathrm{C} 3 \mathrm{H} / \mathrm{HeN}$ mice in the absence of Spirulina LPS markedly suppressed tumor growth and augmented IFN- $\gamma$ responses. Thus, our results support the notion that IFN- $\gamma$ and IL-17/IL-23 mutually regulate Th17 and Th1 responses in tumor-bearing hosts, and Spirulina LPS modulates the balance of the IFN- $\gamma$-IL-17/IL-23 axis towards IFN- $\gamma$ production, which leads to tumor inhibition. Furthermore, Spirulina LPS effectively inhibited the
\end{abstract}

Correspondence to: Dr Shiro Ono, Laboratory of Immunology, Faculty of Pharmacy, Osaka Ohtani University, 3-11-1 Nishikiori-kita, Tondabayashi, Osaka 584-8540, Japan

E-mail: onos@osaka-ohtani.ac.jp

Key words: IL-17, IFN- $\gamma$, tumor immunity, TLR4, Spirulina LPS spontaneous development of mammary tumors. This study has important implications for the exploitation of TLR-based immunomodulators for cancer immunotherapy.

\section{Introduction}

Although the immune system generally recognizes abnormal proteins on tumor cells as tumor antigens, spontaneous immune responses are too weak to suppress tumor growth. To overcome this problem, a variety of adjuvants, including toll-like receptor (TLR) ligands, are investigated to potentiate antitumor immunity. The bacillus Calmette-Guérin (BCG), historically known for its effective adjuvant properties, is often used in the treatment of cancer patients (1).

The innate immune system recognizes pathogen-associated molecular patterns expressed on microorganisms through corresponding TLRs, and the activation of innate immunity by TLRs produces proinflammatory cytokines such as interleukin (IL)-6 and IL-12, leading to the subsequent induction of adaptive immune responses $(2,3)$. IL-12 is produced by macrophages (MФ) and dendritic cells (DC) and dictates the differentiation of CD4 Th1 cells, which produce interferon (IFN) $-\gamma$ and activate natural killer (NK) cells and cytotoxic CD8 T cells (4). IFN- $\gamma$ plays an important role in the prevention of primary tumor development and intracellular pathogen invasion (5-7). Among the different TLR ligands, lipopolysaccharide (LPS) from gram-negative bacteria exhibits antitumor activity in addition to marked toxicity (8). The study of the bioactivity of LPS from various species revealed that LPS prepared from Bordetella pertussis and a synthetic analog of the LPS lipid A subunit are less toxic than E. coli LPS, and display antitumor effects $(9,10)$.

Recent studies have revealed that IL-23/IL-17 signaling plays an important role in tumorigenesis and metastasis in humans and in mice (11-16). IL-17 is primarily produced by $\mathrm{T}$ cells and acts on tumor cells and tumor-associated stromal cells to induce angiogenesis and the production of IL-6, IL-8, and matrix metalloproteinases. IL-23 is produced by 
$\mathrm{M} \phi / \mathrm{DC}$ and facilitates the expansion and survival of IL-17producing CD4 $\mathrm{T}$ (Th17) cells and therefore, the production of IL-17 (17,18). Moreover, it has become evident that a combination of IL- 6 and transforming growth factor (TGF)- $\beta$ induces Th17 differentiation from naive $\mathrm{T}$ cells $(19,20)$. Since $\mathrm{M} \phi / \mathrm{DC}$ produces both antitumor (IL-12) and tumorpromoting (IL-6/IL-23) cytokines upon stimulation with TLR ligands $(21,22)$, the regulation of this balance is critical for TLR-based cancer immunotherapy $(17,18)$. Moreover, IL-17 stimulates tumor cells and tumor-surrounding cells to induce IL-6 expression, which in turn leads to the activation of signal transducer and activator of transcription 3 (STAT3) $(16,23)$. STAT3 is linked to numerous oncogenic signaling pathways and is constitutively activated both in tumor cells and in immune cells under tumor microenvironment-like conditions. Thus, ideal candidate molecules for tumor immunotherapy are TLR-based immunomodulators that do not induce or partially induce IL-6/IL-23.

While exploring TLR4 responsiveness of the material extracted from algae and cyanobacteria (24), we found that LPS phenol-water extracts from Spirulina (Arthrospira) were able to induce IL-12. Noteworthy, Spirulina LPS showed a much lower in vitro induction of IL- 6 and IL-23 by M $\phi / D C$ than E. coli LPS. Spirulina is a gram-negative, oxygenic, photosynthetic, filamentous cyanobacterium (blue-green alga), and since the Aztec civilization in Mexico, it has been widely used as a nutritional and therapeutic supplement (25). Spirulina LPS is reported to be less toxic compared to LPS from Salmonella abortus (26), but its effects on cytokine production or antitumor activities have not been studied extensively. Thus, it would be very interesting to study how Spirulina LPS affects tumor growth and in vivo production of inflammatory cytokines.

Although most experiments examined the in vitro production of IL-17-associated inflammatory cytokines thus far, the expression patterns of these cytokines in tumor host tissue remain to be established. We report here that Spirulina LPS did not induce or only partially induced IL-6 and IL-23 and efficiently suppressed the growth of hepatocellular carcinoma MH134 in a TLR4-dependent manner, by reducing the serum levels of IL-17 and IL-23, while increasing those of IFN- $\gamma$. Interestingly, anti-IL-17 monoclonal antibodies (mAb) clearly suppressed tumor growth as efficiently as Spirulina LPS. Furthermore, Spirulina LPS was quite effective in inhibiting spontaneous development of mammary tumors in an oncogene transgenic mouse model.

\section{Materials and methods}

Mice and tumor cells. Female $\mathrm{C} 3 \mathrm{H} / \mathrm{HeN}$ and $\mathrm{C} 3 \mathrm{H} / \mathrm{HeJ}$ mice were purchased from CLEA Japan Inc. (Tokyo, Japan). DO11.10 transgenic mice for $\alpha \beta$ T-cell receptor (TCR) recognizing ovalbumin (OVA) in the context of I-A ${ }^{\mathrm{d}}$ and transgenic mice carrying an activated rat HER-2/neu oncogene driven by a mouse mammary tumor virus promoter (HER-2/neu mice) were obtained from Jackson Laboratory (Bar Harbor, ME, USA) and Charles River Laboratories (Cambridge, MA, USA), respectively. All mice were maintained in a pathogenfree environment, and experiments were performed following the ethical guidelines of Kochi Medical School and Osaka
Ohtani University. The mouse tumor MH134 (hepatocellular carcinoma; kindly provided by Dr T. Kudo, Tohoku University, Sendai, Japan) and YAC-1 (T-cell lymphoma) cell lines were maintained in RPMI-1640 medium (SigmaAldrich, St. Louis, MO, USA) with $10 \%$ heat-inactivated fetal calf serum (FCS, HyClone Laboratories, Logan, UT, USA), $5 \times 10^{-5}$ M 2-mercaptoethanol (2-ME), and $50 \mu \mathrm{g} / \mathrm{ml}$ gentamicin (Sigma-Aldrich).

Reagents. LPS from Escherichia coli (E. coli) 0111:B4 was purchased from Difco (Detroit, MI, USA). Anti-IFN- $\gamma$ mAb (R4-6A2, rat IgG1; no. MM701), anti-IL-17 mAb (50104, rat IgG2a; no. MAB421), anti-CD8 mAb (53-6.7, rat IgG2a; no. 100735), and rat IgG were obtained from Endogen (Rockford, IL, USA), R\&D Systems (Minneapolis, MN, USA), BioLegend (San Diego, CA, USA), and Sigma-Aldrich, respectively. Anti-CD4 mAb (GK1.5, rat IgG2b) was kindly provided by Dr F.W. Fitch (University of Chicago, Chicago, IL, USA).

Preparation of LPS from Spirulina pacifica. S. pacifica was a generous gift from Dr Genrald Cysewski (Cyanotech Corporation, Kailua-Kona, Hawaii, USA) and Mr. Nobuyuki Miyaji (Toyo Koso Kagaku Co., Ltd., Chiba, Japan). S. pacifica has been selected from a strain of edible S.platensis in 1984 and its enzyme expression profile differs from that of the parental strain. LPS was prepared from S. pacifica freeze-dried cells as previously described (27). Briefly, cells were washed with acetone, suspended in distilled water, and then extracted by addition of $90 \%$ phenol-water and vigorous agitation at $68^{\circ} \mathrm{C}$. The crude preparation was dialyzed to remove phenol and residual freeze-dried cells. The sample was dissolved in water, and the insoluble material was eliminated by centrifugation, followed by ultracentrifugation at $100,000 \times \mathrm{g}$. The molecular mass of the LPS sample was estimated between approximately 1,000 and 20,000 Da by electrophoresis and mass spectral analysis.

Tumor growth in vivo. Tumor growth was measured 3 times per week after intradermal (i.d.) injection of $1 \times 10^{6} \mathrm{MH} 134$ cells in the back of $\mathrm{C} 3 \mathrm{H} / \mathrm{HeN}$ or $\mathrm{C} 3 \mathrm{H} / \mathrm{HeJ}$ mice. The tumor volume was calculated using the following formula: Volume $\left(\mathrm{mm}^{3}\right)=$ width $^{2} \mathrm{x}$ length $/ 2$. In some experimental settings, Spirulina LPS or E. coli LPS in saline solution was injected intraperitoneally (i.p.) every week starting 6 days after tumor inoculation. To deplete the T-cell subsets, mice injected with MH134 tumor cells on day 0 were injected i.p. with rat $\mathrm{IgG}$, anti-CD4, or anti-CD8 mAb (150 $\mu \mathrm{g} /$ mouse on days, $-1,0,+3)$ as previously described (28). T-cell depletion was confirmed to be $>95 \%$ by fluorescence-activated cell sorting (FACS).

Surgical tumor resection and rechallenge. MH134 tumors were surgically removed 3 weeks after tumor inoculation. Mice were re-challenged i.d. with $1.5 \times 10^{6} \mathrm{MH} 134$ cells of the same tumor as previously described (29).

Immunohistochemistry. MH134 tumors taken from $\mathrm{C} 3 \mathrm{H} / \mathrm{HeN}$ mice treated with saline solution or Spirulina LPS 22 days after tumor implantation were embedded in O.C.T. compound (Sakura Finetec USA, Inc., Torrance, CA, USA) and frozen. Frozen tumors were sectioned and stained with anti-CD4 
(RM4-5, rat IgG2a, no. 100520, BioLegend) or anti-CD8 (53-6.7) antibodies using simple stain mouse MAX-PO [F(ab)' ${ }_{2}$ goat anti-rat Ig and peroxidase coupled to the amino acid polymer] and 3,3'-diaminobenzidine according to the manufacturer's protocol (Nichirei-Biosciences Inc., Tokyo, Japan).

Preparation of lymphoid cells. M $\phi / \mathrm{DC}$ or CD4 T cell fractions were prepared from whole spleen cells by positive selection using a MACS cell separation system (Miltenyi Biotec, Auburn, CA, USA) according to manufacturer's instructions. Anti-CD4 and a mixture of anti-CD11b and anti-CD11c microbeads were used for the fractionation of CD4 T cells and $\mathrm{M} \phi / \mathrm{DC}$, respectively. The purity was usually demonstrated to be $>90 \%$ by FACS.

Culture of splenocytes from tumor-bearing mice. Whole splenocytes $\left(5 \times 10^{6} /\right.$ well $)$ depleted of red blood cells were cultured in 10\% FCS RPMI-1640 medium in 24-well culture plates (Becton Dickinson Labware, Franklin Lakes, NJ, USA) at $37^{\circ} \mathrm{C}$ in a $5 \% \mathrm{CO}_{2}$ humidified atmosphere. After 4 days of culture, supernatants were collected to assess cytokine levels by ELISA.

In vitro IL-17 production. Whole spleen cells $\left(8 \times 10^{5} /\right.$ well $)$ from OVA-specific TCR transgenic (DO11.10) mice were cultured in flat-bottomed 96-well plates (Costar Corning, NY, USA) in $10 \%$ FCS RPMI-1640 medium for 5 days. In some experiments, $2.8 \times 10^{5} \mathrm{CD} 4 \mathrm{~T}$ cells, prepared from $\mathrm{C} 3 \mathrm{H} /$ HeJ mice that had been immunized i.p. with $150 \mu \mathrm{g}$ OVA and $5 \mathrm{mg}$ Alum approximately 2 months earlier, were cultured with $1.2 \times 10^{5}$ splenic $\mathrm{M} \phi / \mathrm{DC}$ cells from $\mathrm{C} 3 \mathrm{H} / \mathrm{HeN}$ or $\mathrm{C} 3 \mathrm{H} / \mathrm{HeJ}$ mice in the presence of $20 \mu \mathrm{g} / \mathrm{ml}$ OVA for 5 days. Spirulina or E. coli LPS was added at the initiation of the culture to evaluate its effect on IL-17 production. The levels of IL-17 in the culture supernatants were evaluated by ELISA.

$B$ cell proliferation. Whole spleen cells $\left(8 \times 10^{5} /\right.$ well) were cultured in flat-bottomed 96 -well plates in $10 \%$ FCS RPMI-1640 medium in the presence or absence of graded doses of Spirulina LPS or E. coli LPS. Five days later, the cultured cells were collected and stained with FITCconjugated anti-B220 mAb (RA3-6B2, rat IgG2a, no. 553088, BD Biosciences, San Jose, CA, USA). B220 ${ }^{+}$cells were counted as B cells using a FACSCalibur instrument (Becton Dickinson, San Jose, CA, USA).

NK assay. Briefly, $2.5 \times 10^{6}$ target cells were labeled with $25 \mu \mathrm{Ci}$ of ${ }^{51} \mathrm{Cr}$ sodium chromate for $60 \mathrm{~min}$ at $37^{\circ} \mathrm{C}$ in $10 \%$ FCS RPMI-1640 medium. After washing, ${ }^{51} \mathrm{Cr}$-labeled target cells $\left(1 \times 10^{4}\right)$ and effector cells were mixed in flat-bottomed 96-well plates at the indicated effector/target (E/T) ratio. After $4 \mathrm{~h}$ of incubation, the radioactivity in the cell-free supernatants was measured using a 1470 Automatic Gamma Counter (PerkinElmer, Waltham, MA, USA). Percentage-specific lysis for ${ }^{51} \mathrm{Cr}$ release was calculated according to the following formula: \% specific lysis $=[($ experimental - spontaneous $)$ release] / [(maximal - spontaneous) release $\mathrm{x} 100$.

ELISA for cytokine measurement. Cytokine levels in serum or culture supernatants were quantified by sandwich ELISA.
The following pairs of capture and biotinylated detection rat anti-mouse mAbs were used: R4-6A2 (no. 551216) and XMG1.2 (no. 554410) for IFN- $\gamma$, TC11-18H10 (no. 555068) and TC11-8H4 (no. 555067) for IL-17, 9A5 (no. 554658) and C17.8 (no. 554476) for IL-12(p35/40), MP5-20F3 (no. 554400) and MP5-32C11 (no. 554402) for IL-6, and A75-2 (no. 555052) and A75-3 (no. 555053) for TGF- $\beta 1$ (all were purchased from BD Biosciences). For IL-23(p19/40), rat anti-mouse IL-23p19 (G23-8, no. 14-7232-85, eBioscience, San Diego, CA, USA) and biotinylated anti-IL-12p40 (C17.8, BD Biosciences) were used. The ELISA assays were performed according to the manufacturer's instructions.

Statistical analysis. Differences in mean values between groups were calculated using an unpaired two-tailed Student's t-test, Mann-Whitney U test, or Fischer's exact test. P-values of the Student's t tests are shown unless otherwise indicated.

\section{Results}

TLR4-dependent suppression of tumor growth by Spirulina LPS is mediated by CD4 and CD8 T cells. To examine the antitumor activities of Spirulina LPS in comparison with that of E. coli LPS, we inoculated hepatocellular carcinoma MH134 cells i.d. into syngeneic $\mathrm{C} 3 \mathrm{H} / \mathrm{HeN}$ and TLR4 mutant $\mathrm{C} 3 \mathrm{H} / \mathrm{HeJ}$ mice (30), followed by i.p. administration of different doses of Spirulina LPS or E. coli LPS 6 days later. The injection with different doses of Spirulina LPS suppressed the tumor growth in $\mathrm{C} 3 \mathrm{H} / \mathrm{HeN}$ but not in $\mathrm{C} 3 \mathrm{H} / \mathrm{HeJ}$ mice, to the same degree as E. coli LPS treatment (Fig. 1A). This suggests that Spirulina LPS as well as E. coli LPS reduced tumor growth in a TLR4dependent manner.

In order to assess the involvement of T cells in the Spirulina LPS-induced antitumor effect, we administered anti-CD4 and/or anti-CD8 mAbs to deplete the T-cell subsets before Spirulina LPS injection. While injection of both anti-CD4 and anti-CD8 mAbs completely abolished the antitumor activity of Spirulina LPS, anti-CD4 or anti-CD8 mAb alone did not result in a strong effect (Fig. 1B). In accordance with the results of the in vivo T-cell depletion, immunohistochemical examinations revealed the enhancement of infiltration of both CD4 and CD8 T cells in the tumor masses upon administration of Spirulina LPS (Fig. 1C). These results suggest that CD4 and CD8 T cells are both involved in the antitumor effect induced by Spirulina LPS.

Spirulina and E. coli LPS differ in their ability to activate NK cells and induce secondary immune responses. To examine whether Spirulina LPS induces immunity against MH134 tumors, we reinoculated $\mathrm{MH} 134$ cells into $\mathrm{C} 3 \mathrm{H} / \mathrm{HeN}$ mice that had been implanted with an MH134 tumor and were treated with saline, E. coli, or Spirulina LPS, followed by surgical resection of primary tumors 5 days before the re-challenge. The growth rate of the reimplanted tumors reduced even in saline-treated mice, compared with that in untreated mice implanted with only new tumor cells without the first inoculum of MH134 tumor cells (Fig. 2A), implicating the induction of antitumor immunity without LPS administration when the primary tumor was removed. Spirulina LPS induced a stronger resistance to reimplanted MH134 tumors than saline (Fig. 2A). 
A

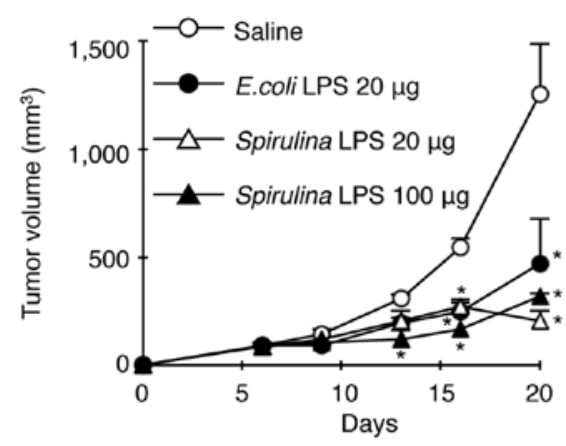

$\mathrm{C} 3 \mathrm{H} / \mathrm{HeJ}$

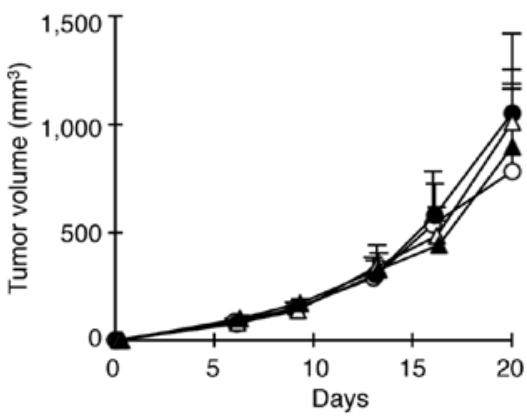

C

CD4 T cells staining

CD8 T cells staining
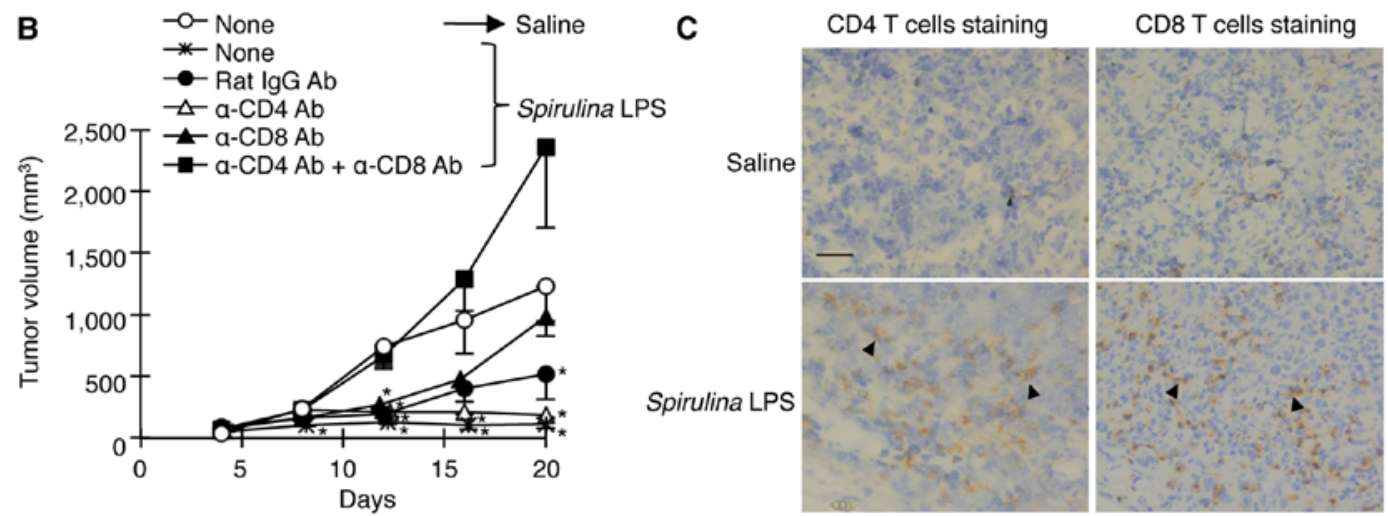

Figure 1. T cell-mediated suppression of tumor growth by Spirulina LPS through TLR4. (A) MH134 tumor cells were injected i.d. into C3H/HeN and C3H/HeJ mice on day 0. Spirulina LPS, E. coli LPS, or saline was injected i.p. on days 6, 13, and 20. Data represent mean \pm standard error (SE) of 5 mice per group. ${ }^{*} \mathrm{P}<0.05$ compared with saline. (B) The tumor-bearing $\mathrm{C} 3 \mathrm{H} / \mathrm{HeN}$ mice were treated with anti-CD4 and/or anti-CD8 or control rat IgG antibodies on days $-1,0$, and 3, followed by saline or Spirulina LPS $(100 \mu \mathrm{g})$ i.p. injection on days 8, 13, and 20 . Data represent mean $\pm \mathrm{SE}$ of 5 mice per group. ${ }^{*} \mathrm{P}<0.05$ compared with saline. (C) MH134 tumors were taken from C3H/HeN mice treated with saline or Spirulina LPS (20 $\mu \mathrm{g}) 22$ days after tumor implantation and tumor sections were stained with anti-CD4 or anti-CD8 antibody. Arrows show CD4 T or CD8 T lymphocytes (brown). Bar: $50 \mu \mathrm{m}$.

In contrast, the tumor growth rate in E. coli LPS-treated mice was comparable to that in saline-treated mice (Fig. 2A). These results suggest that while Spirulina LPS facilitated the generation of immunity against MH134 tumors, E. coli LPS did not enhance secondary antitumor immune response. Since $E$. coli LPS was effective in the prevention of primary tumor growth as shown in Fig. 1A and is known to exhibit antitumor activity partly through activation of NK cells, we evaluated the ability of $E$. coli and Spirulina LPS to activate NK cells. Indeed, spleen cells from $\mathrm{C} 3 \mathrm{H} / \mathrm{HeN}$ mice injected with $E$. coli LPS showed remarkable toxicity towards NK-sensitive YAC-1 cells and a weak but significant toxicity towards MH134 cells, whereas Spirulina LPS failed to activate NK cells (Fig. 2B). $\mathrm{NK}$ activation was not induced in $\mathrm{C} 3 \mathrm{H} / \mathrm{HeJ}$ mice, not even when E. coli LPS was administered (Fig. 2B). Thus, this result may explain why $E$. coli LPS elicited antitumor effects against the primary tumor, regardless of its failure to enhance adaptive immunity to tumors.

Administration of Spirulina LPS to a tumor-bearing host downregulates serum levels of IL-17 and IL-23 but increases IFN- $\gamma$ production by $T$ cells through the TLR4 pathway. IFN- $\gamma$ plays a crucial role in the prevention of tumor development (6), whereas IL-17 and IL-23 are considered to promote tumor growth by inducing inflammation and by regulating the expansion/survival of Th17 cells, respectively (11,14-16). We measured serum levels of IFN- $\gamma$, IL-17, and IL-23 in tumor- bearing $\mathrm{C} 3 \mathrm{H} / \mathrm{HeN}$ and $\mathrm{C} 3 \mathrm{H} / \mathrm{HeJ}$ mice treated with saline, E. coli, or Spirulina LPS. E. coli and Spirulina LPS $(100 \mu \mathrm{g})$ markedly increased serum IFN- $\gamma$ levels in $\mathrm{C} 3 \mathrm{H} / \mathrm{HeN}$ mice with a peak response at days 7 and 14 after tumor inoculation, respectively (Fig. 3A). A low dose of Spirulina LPS (20 $\mu \mathrm{g})$ induced slight but significant IFN- $\gamma$ production from days 7 to 14. However, the serum levels of IFN- $\gamma$ were not elevated in $\mathrm{C} 3 \mathrm{H} / \mathrm{HeJ}$ mice at any time, not even after injection of either LPS. The treatment with anti-CD4 $\mathrm{mAb}$ or a combination of anti-CD4 and anti-CD8 mAbs abrogated the increase in serum IFN- $\gamma$ in $\mathrm{C} 3 \mathrm{H} / \mathrm{HeN}$ mice receiving Spirulina LPS, whereas anti-CD8 $\mathrm{mAb}$ alone slightly diminished the activity of Spirulina LPS to induce IFN- $\gamma$ (Fig. 3D). On the other hand, serum levels of IL-17 and IL-23 in saline-treated $\mathrm{C} 3 \mathrm{H} / \mathrm{HeN}$ mice gradually increased during tumor progression and reached a maximum on day 21 (Fig. 3B and C). However, serum levels of IL-6 only showed an approximately 2 -fold increase in saline-treated tumor-bearing mice even on day 21 as compared to non-treated mice (data not shown). Noteworthy, Spirulina LPS significantly reduced IL-17 and IL-23 levels, while $E$. coli LPS hardly suppressed IL-17 production on day 21 (Fig. 3B and C). On the contrary, E. coli LPS enhanced serum levels of IL-23 in tumor-bearing $\mathrm{C} 3 \mathrm{H} /$ HeN mice on day 7 and 14. Taken together, these results support the notion that Spirulina LPS induces antitumor immune responses through the induction of IFN- $\gamma$ mostly by CD4 T cells and suppressed serum levels of IL-17 and IL-23, 


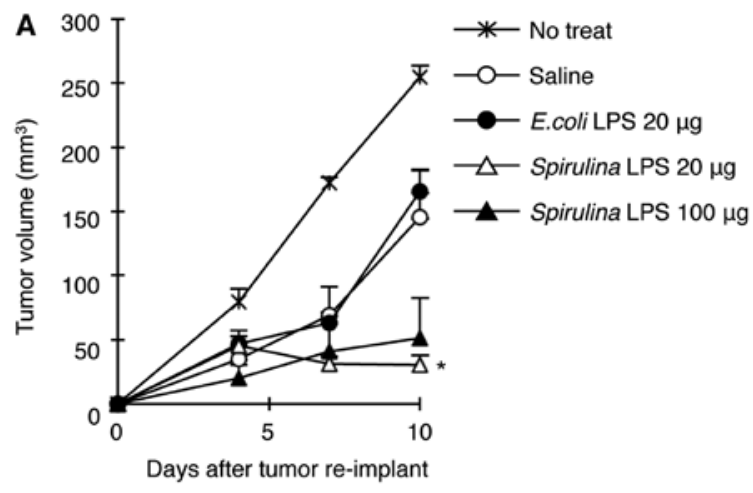

B

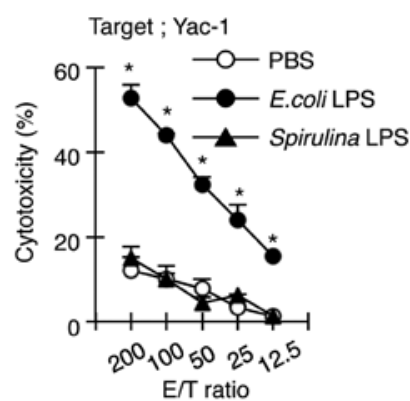

Target ; $\mathrm{MH}-134$

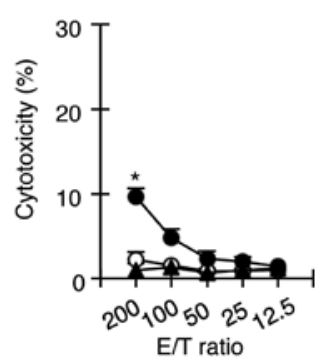

C3H/HeJ

Target ; Yac-1

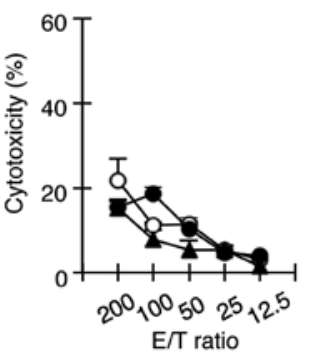

Figure 2. Spirulina LPS is incapable of activating NK cells but elicits immunity against reimplanted tumors. (A) MH134 tumors from E. coli or Spirulina LPS-treated $\mathrm{C} 3 \mathrm{H} / \mathrm{HeN}$ mice were surgically removed on day 22, and rechallenged with MH134 tumors on day 27 . Tumor growth was measured. Data represent mean $\pm \mathrm{SE}$ of 3-5 mice per group. ${ }^{*} \mathrm{P}<0.05$ compared with saline. (B) Freshly prepared spleen cells from $\mathrm{C} 3 \mathrm{H} / \mathrm{HeN}$ or $\mathrm{C} 3 \mathrm{H} / \mathrm{HeJ}$ mice treated with $\mathrm{PBS}, E$. coli, or Spirulina LPS were co-cultured with ${ }^{51} \mathrm{Cr}$-labeled YAC-1 or MH134 cells. The cytolytic activity of NK cells against YAC-1 or MH134 target cells was assessed in a chromium release assay. ${ }^{*} \mathrm{P}<0.05$ compared with $\mathrm{PBS}$.

whereas E. coli LPS exerts its antitumor effect primarily through activation of NK cells.

We have previously shown that antigen-presenting cells (APCs)-expressing tumor Ag and tumor-reactive T cells are both stimulated in vivo in tumor-bearing mice, and that in vitro culture of spleen cells from tumor-bearing mice at early stages leads to cytokine production without exogenous addition of tumor Ag as a result of the collaboration between antitumor T cells and APCs $(29,31)$. We tested whether in vivo treatment with E. coli or Spirulina LPS affects the in vitro production of IFN- $\gamma$ by culturing spleen cells from MH134 tumor-bearing mice. Spirulina LPS clearly enhanced IFN- $\gamma$ production in spleen cells of tumor-bearing $\mathrm{C} 3 \mathrm{H} / \mathrm{HeN}$ mice, whereas $E$. coli LPS was unable to upregulate IFN- $\gamma$ production (Fig. 3D). These results implicate that Spirulina LPS enhances IFN- $\gamma$ production through the generation of memory T cells.

Spirulina LPS inhibits IL-17 production in an IFN- $\gamma$ independent manner through interaction with APCs expressing TLR4. Since Spirulina LPS reduced serum IL-17 levels in tumor-bearing mice while increasing IFN- $\gamma$ levels and because IFN- $\gamma$ negatively regulates the generation of Th17 cells $(32,33)$, we investigated whether IL-17 downregulation by Spirulina LPS occurs via inhibition of the induction of IL-17-producing cells by facilitating IFN $-\gamma$ production, or alternatively by directly downregulating IL-17-producing cells. To address this question, spleen cells from OVA-specific TCR transgenic DO11.10 mice were stimulated by OVA with or without $E$. coli or Spirulina LPS and in the presence or absence of anti-IFN- $\gamma$ $\mathrm{mAb}$. Spirulina LPS significantly suppressed IL-17 production by DO11.10 spleen cells in a dose-dependent manner, regardless of the presence of anti-IFN- $\gamma$ mAb. However, E. coli LPS augmented IL-17 production (Fig. 4A), possibly because of its ability to induce IL-6 (Fig. 5A). In addition, it is noteworthy that anti-IFN- $\gamma$ mAb enhanced IL-17 production by DO11.10 spleen cells in response to OVA without the addition of either LPS (Fig. 4A), indicating that IFN- $\gamma$ regulates IL-17-producing cells. Thus, Spirulina LPS suppresses the in vivo production of IL-17 with or without involvement of IFN- $\gamma$. Moreover, although Spirulina LPS inhibited IL-17 production when CD4 $\mathrm{T}$ cells from OVA-primed $\mathrm{C} 3 \mathrm{H} / \mathrm{HeJ}$ mice were co-cultured with $\mathrm{C} 3 \mathrm{H} / \mathrm{HeN}$ APCs in the presence of OVA, it failed to suppress IL-17 production when OVA-primed C3H/HeJ CD4 $\mathrm{T}$ cells were stimulated with OVA in the context of $\mathrm{C} 3 \mathrm{H} / \mathrm{HeJ}$ APCs (Fig. 4B). These results suggest that Spirulina LPS acted on APCs to inhibit the generation of Th17 cells in a TLR4dependent manner.

Anti-IL-17 mAb administration inhibits tumor development upon elevated IFN- $\gamma$ production. Thus far, our results are consistent with the notion that the antitumor effect of Spirulina LPS is caused by the downregulation of IL-17 production. To examine whether neutralization of IL-17 by anti-IL-17 mAb would result in a reduction of tumor growth in mice in the absence of Spirulina LPS, we injected antiIL-17 or anti-IFN- $\gamma$ mAb into $\mathrm{C} 3 \mathrm{H} / \mathrm{HeN}$ mice 1 day before 


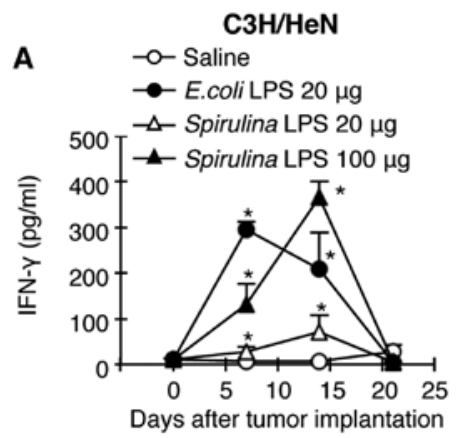

$\mathrm{C} 3 \mathrm{H} / \mathrm{HeJ}$
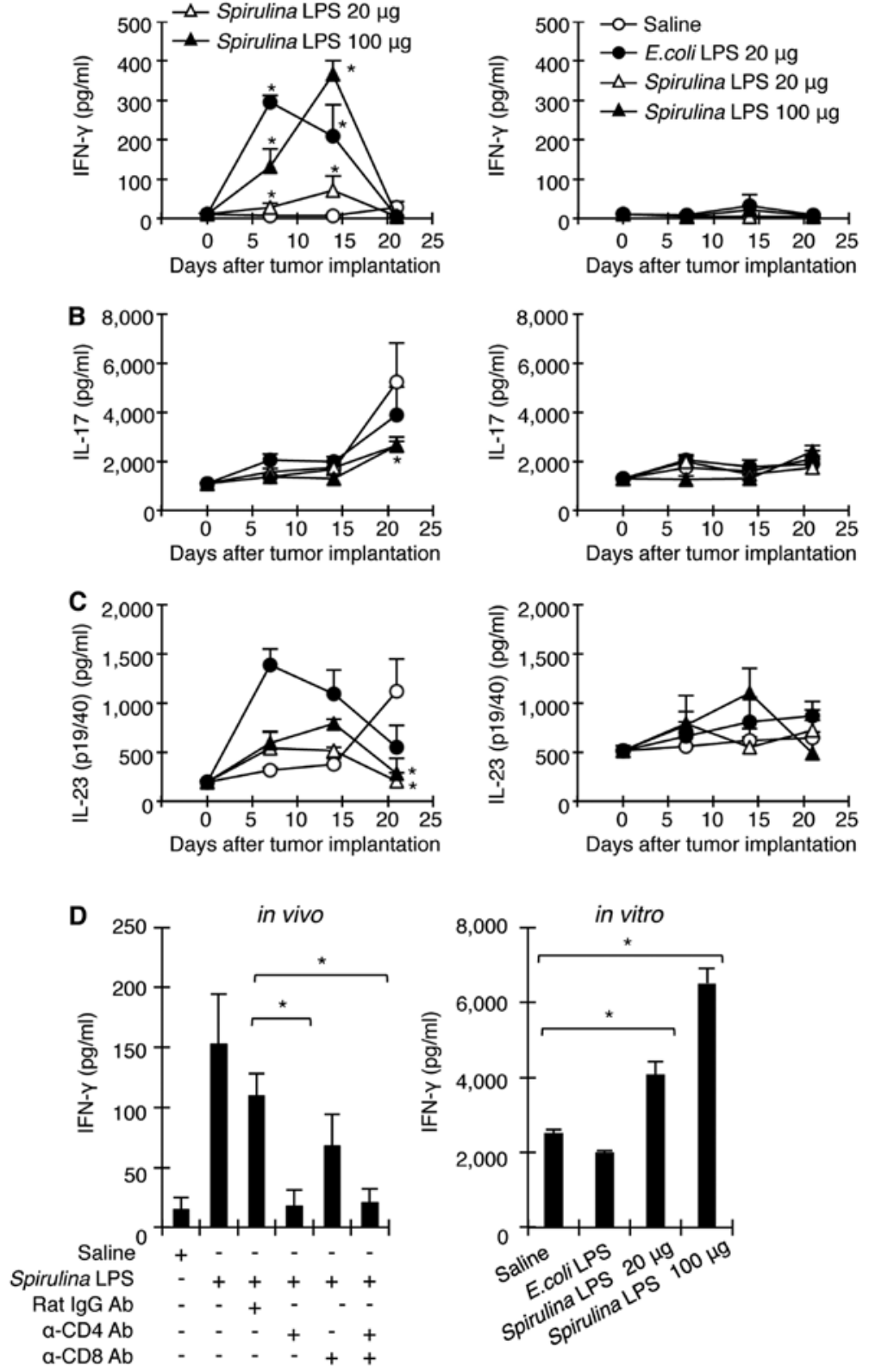

Figure 3. Administration of Spirulina LPS to tumor-bearing mice decreases serum IL-17 and IL-23 levels, while increasing IFN- $\gamma$ levels through the TLR4 pathway. (A-C) Serum cytokine levels were measured in tumor-bearing $\mathrm{C} 3 \mathrm{H} / \mathrm{HeN}$ or $\mathrm{C} 3 \mathrm{H} / \mathrm{HeJ}$ mice treated with LPS as in Fig. 1A. Data represent mean $\pm \mathrm{SE}$ of 5 mice per group. " $\mathrm{P}<0.05$ compared with saline. (D) Tumor-bearing $\mathrm{C} 3 \mathrm{H} / \mathrm{HeN}$ mice were treated with anti-CD4 and/or anti-CD8, or rat IgG antibodies (on days $-1,0$, and 3) and Spirulina LPS (on days 8, 13, and 20), and serum IFN- $\gamma$ levels were measured 14 days after tumor implantation (in vivo). Data represent mean \pm SE of 5 mice per group. ${ }^{*} \mathrm{P}<0.05$ compared with rat IgG. Spleen cells from MH134 tumor-bearing C $3 \mathrm{H} / \mathrm{HeN}$ mice treated with E. coli or Spirulina LPS were prepared on day 22 and cultured without exogenous addition of tumor cells for 4 days. The culture supernatant was assessed for IFN- $\gamma\left(\right.$ in vitro). ${ }^{*} \mathrm{P}<0.05$ compared with saline.

and 4 days after MH134 tumor implantation, and monitored tumor development. As expected, anti-IL-17 mAb markedly suppressed tumor growth compared to control rat IgG antibodies, whereas anti-IFN- $\gamma$ mAb slightly enhanced tumor development (Fig. 4C). Importantly, mice receiving anti-IL-17 $\mathrm{mAb}$ exhibited high levels of serum IFN- $\gamma$ (Fig. 4D). In addition, in vitro culture of spleen cells from tumor-bearing mice treated with anti-IL-17 $\mathrm{mAb}$ resulted in the production of large amounts of IFN- $\gamma$ (Fig. 4D). These results indicate that IL-17 provides an environment suitable for tumor growth partly by inhibiting the generation of IFN- $\gamma$-producing T cells.
Spirulina LPS reduces or abrogates IL-6 and IL-23 production in vivo, but augments $T$ cell-dependent IL-12 induction. It was recently reported that IL-17 is mainly produced by Th17 cells, and that both IL- 6 and TGF- $\beta$ are indispensable for the generation of Th17 cells (20). To test the ability of Spirulina LPS to induce IL- 6 and TGF- $\beta$, normal $\mathrm{C} 3 \mathrm{H} / \mathrm{HeN}$ and $\mathrm{C} 3 \mathrm{H} / \mathrm{HeJ}$ mice were injected i.p. with E. coli or Spirulina LPS and serum cytokine levels were measured $4 \mathrm{~h}$ later. $\mathrm{C} 3 \mathrm{H} / \mathrm{HeN}$ mice produced high levels of IL-6 in response to $E$. coli LPS, but showed only a small response upon stimulation with Spirulina LPS (Fig. 5A). Contrary to IL-6, the substantial TGF- $\beta$ levels 
A
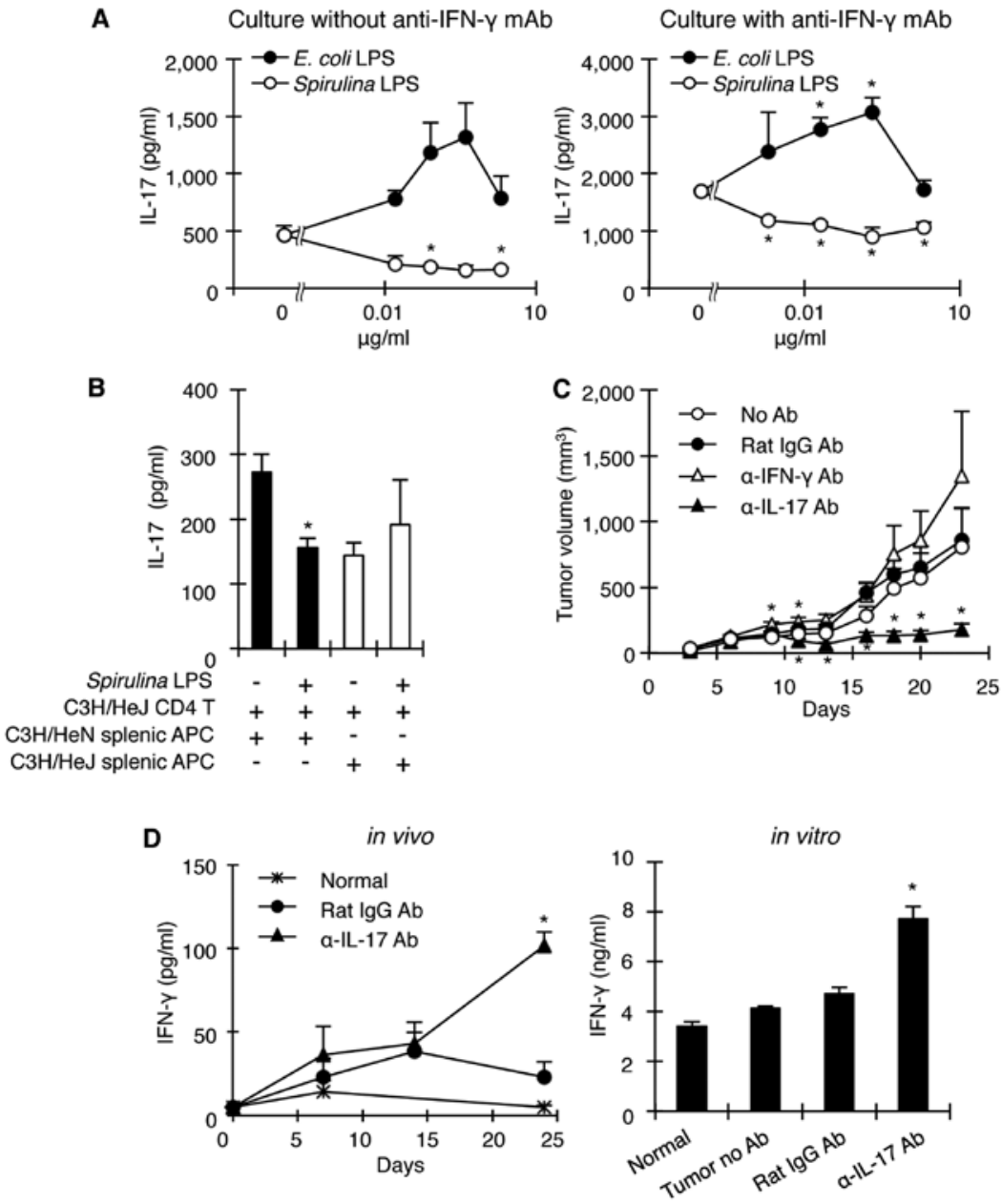

Figure 4. Spirulina LPS inhibits IL-17 production through TLR4 on APCs, and neutralization of endogenous IL-17 in MH134-bearing mice results in tumor regression. (A) Spleen cells from OVA-specific TCR transgenic mice were cultured with OVA in the absence (left) or presence (right) of anti-IFN- $\gamma \mathrm{mAb}$ for 5 days. Graded doses of $E$. coli or Spirulina LPS were further added into the culture to examine their effect on IL-17 production. Background IL-17 production without OVA was $<22 \mathrm{pg} / \mathrm{ml}$. "P $<0.05$ compared with control. (B) CD4 T cells from OVA-primed C3H/HeJ mice and splenic APCs from C3H/HeN or C3H/HeJ mice were co-cultured with OVA in the absence or presence of Spirulina LPS for 5 days. The culture supernatant levels of IL- 17 were measured. "P $<0.05$ compared with no Spirulina LPS. (C) Tumor-bearing C3H/HeN mice were injected with anti-IL-17, anti-IFN- $\gamma$, or control rat IgG antibodies 1 day before and 4 days after tumor implantation. Data represent mean tumor growth $\pm \mathrm{SE}$ of 5 mice per group. ${ }^{*} \mathrm{P}<0.05$ compared with no Ab. (D) In the same experiment as in C, serum IFN- $\gamma$ was measured (in vivo). " $\mathrm{P}<0.05$ compared with Rat IgG. Spleen cells from tumor-bearing mice treated with anti-IL-17 mAb or Rat IgG as in $\mathrm{C}$ were prepared 24 days after tumor implantation and cultured for 4 days to measure the production of IFN $-\gamma\left(\right.$ in vitro). Data represent mean $\pm \mathrm{SE}$. ${ }^{*} \mathrm{P}<0.05$ compared with Rat IgG.

present in serum of untreated groups of both strains were not significantly elevated when stimulated with E. coli LPS (Fig. 5A). However, Spirulina LPS slightly reduced TGF- $\beta$ levels, but only in $\mathrm{C} 3 \mathrm{H} / \mathrm{HeN}$ mice (Fig. 5A). Noteworthy, E. coli LPS elicited a considerable increase in IL-23 levels, only in $\mathrm{C} 3 \mathrm{H} / \mathrm{HeN}$ mice, while Spirulina LPS showed almost no induction of IL-23 even in $\mathrm{C} 3 \mathrm{H} / \mathrm{HeN}$ mice (Fig. 5A). Thus, Spirulina LPS seems to be inferior to E. coli LPS in terms of stimulating immune cells. The possibility that Spirulina LPS has a general defect in the stimulation of immune system was excluded, because both E. coli and Spirulina LPS induced $\mathrm{B}$ cell proliferation in a dose-dependent manner (Fig. 5B).

Since IL-12 and IFN- $\gamma$ are known to play a crucial role in the differentiation of IFN- $\gamma$-producing Th1 cells (4), we measured the serum levels of IL-12 in tumor-bearing mice that were treated with saline, E. coli, or Spirulina LPS. Spirulina LPS augmented IL-12 production more than E. coli LPS. In contrast to a transient increase of IL-12 by E. coli LPS, the enhanced IL-12 production by Spirulina LPS was still observed after 14 days (Fig. 5C). Of note, these high IL-12 serum levels on day 14 decreased when $\mathrm{C} 3 \mathrm{H} / \mathrm{HeN}$ mice were injected with anti-CD4, but not anti-CD8 $\mathrm{mAb}$ (Fig. 5D), implicating CD4 T cell-dependent IL-12 production. Taken together, these findings support the notion that Spirulina LPS facilitates the priming of CD4 T cells with tumor cells and the subsequent CD4 T cell-dependent activation of APCs, leading to IL-12 production, which in turn induces IFN- $\gamma$-producing $\mathrm{T}$ cells.

Spirulina LPS attenuates the spontaneous development of mammary tumors. We finally examined whether Spirulina LPS is also effective in suppressing the spontaneous development of mammary tumors in female transgenic mice carrying the activated HER-2/neu oncogene. HER-2/neu transgenic mice display apparent hyperplasia in the mammary glands at 10 weeks of age and develop palpable mammary tumors around 24 weeks (28). Female HER-2/neu mice were injected with Spirulina LPS or PBS once per week between 120 and 
A

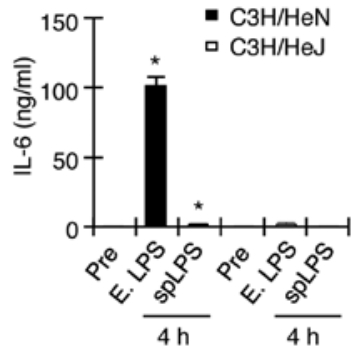

B
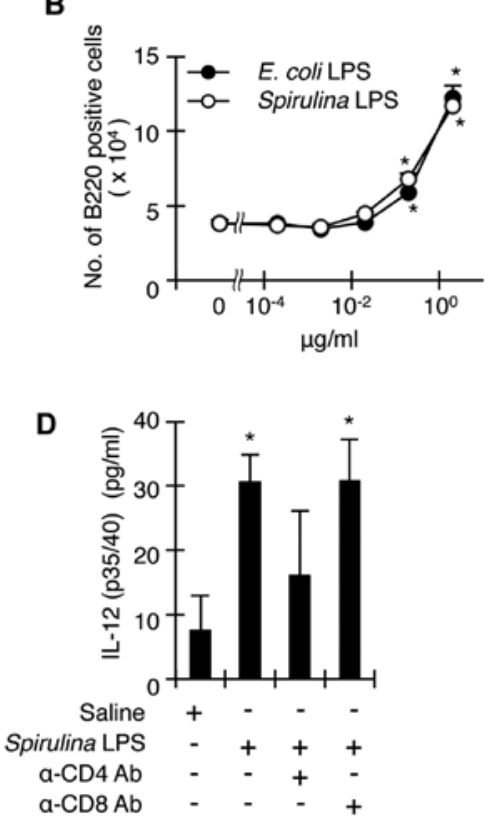
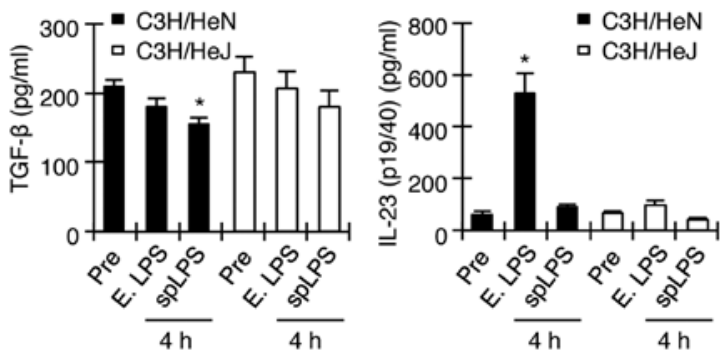

C $\quad \mathrm{C} 3 \mathrm{H} / \mathrm{HeN}$

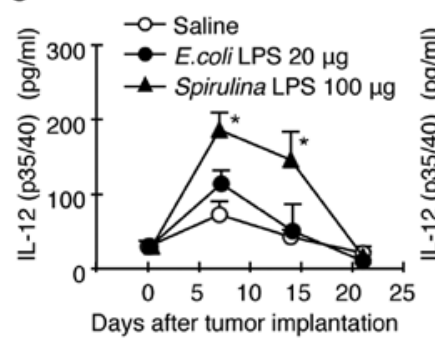

$\mathrm{C} 3 \mathrm{H} / \mathrm{HeJ}$

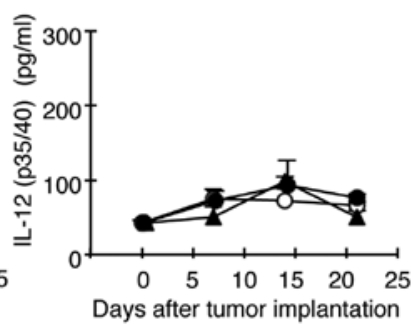

Figure 5. Spirulina LPS induces limited or does not induce the production of IL-6 and IL-23 in vivo, but augments T cell-dependent IL-12 induction. (A) $\mathrm{C} 3 \mathrm{H} / \mathrm{HeN}$ and $\mathrm{C} 3 \mathrm{H} / \mathrm{HeJ}$ mice were injected i.p. with E. coli LPS or Spirulina LPS (200 $\mu \mathrm{g})$. Serum IL-6, TGF- $\beta$, or IL-23 levels were assessed $4 \mathrm{~h}$ later. Data represent mean $\pm \mathrm{SE}$ of 4-5 mice per group. "P<0.05 compared with prior to injection (pre). (B) Whole spleen cells from DO11.10 mice were cultured in the presence of E. coli or Spirulina LPS without OVA for 5 days and B-cell proliferation was estimated. "P<0.05 compared with no LPS. (C) Serum IL-12 levels were measured in tumor-bearing $\mathrm{C} 3 \mathrm{H} / \mathrm{HeN}$ or $\mathrm{C} 3 \mathrm{H} / \mathrm{HeJ}$ mice treated as in Fig. 1A. Data represent mean $\pm \mathrm{SE}$ of 5 mice per group. "P<0.05 compared with saline. (D) Tumor-bearing C3H/HeN mice were treated with Spirulina LPS and with anti-CD4 and/or anti-CD8, or rat IgG antibodies as in Fig. 1B. Serum levels of IL-12 were measured on day $14 .{ }^{*} \mathrm{P}<0.05$ compared with saline.

240 days after birth. Spirulina LPS delayed the appearance of tumors and significantly reduced both tumor incidence and growth (Fig. 6).

\section{Discussion}

The IL-12/IFN- $\gamma$ pathway is crucial for antitumor immunity by inducing IFN- $\gamma$-producing CD4 and CD8 T cells $(4,6,7,34)$. In this context, various adjuvants including microbial products are explored to potentiate antitumor immunity. On the other hand, IL-23/IL-17 signaling plays an important role in tumorigenesis and metastasis in humans and mice by inducing angiogenesis and IL-6, IL-8, and matrix metalloproteinase expression (11-17). Since most adjuvants induce IL-6, which is indispensable for Th17 differentiation, adjuvants that do not induce or slightly induce IL-6 are desired for tumor immunotherapy. The present study demonstrates that Spirulina LPS is a very poor inducer of IL- 6 and IL-23 and that it elicits strong antitumor immunity by suppressing IL-17 induction while enhancing IFN- $\gamma$ production through the TLR4 pathway.

In a tumor-based mouse model, Spirulina LPS treatment enhanced serum levels of IFN- $\gamma$ at early stages of tumor development and decreased serum IL-17 and IL-23 levels at later stages (Fig. 3). Spirulina LPS also induced IL-12 production in a $\mathrm{CD} 4 \mathrm{~T}$ cell-dependent manner, probably through CD4 T cell-APC interaction (Fig. 5C and D), and induced IFN- $\gamma$ production primarily by CD4 T cells. Based on previous reports on the inhibition of Th17 differentiation by IFN- $\gamma(32,33)$, these results can be interpreted as follows: Spirulina LPS facilitates the differentiation of tumor-primed CD4 T cells to Th1 cells. Subsequently, Th1-derived IFN- $\gamma$ prevents Th17 differentiation and promotes CD8 T-cell activation. In addition, Spirulina LPS might also suppress IL-17 production through IFN- $\gamma$-independent pathways as shown in our in vitro experiments (Fig. 4A).

Alternatively, it is possible that although IL-17 elevation during tumor progression could prevent the generation of IFN- $\gamma$-producing T cells, Spirulina LPS might restore the generation of Th1 cells by reducing IL-17 production (Fig. 3). Recent experiments have revealed IL-17-mediated inhibition of Th1 differentiation (35). It is also conceivable that Spirulina LPS inhibits tumor growth by reducing IL-17induced angiogenesis, as previously reported (11-13,36). Of note, administration of anti-IL-17 mAb into tumor-bearing 

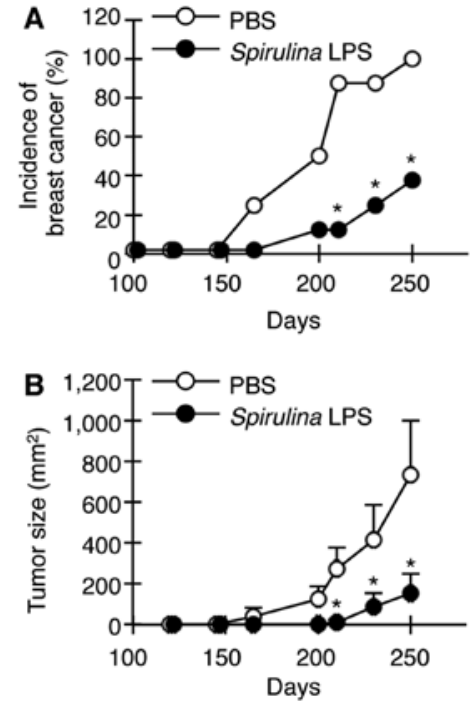

Figure 6. Spirulina LPS suppresses the spontaneous development of mammary tumors. HER-2/neu transgenic mice were injected i.p. with Spirulina LPS $(80 \mu \mathrm{g})$ or PBS every week between 120 and 240 days after birth. A palpable node over $5 \times 5 \mathrm{~mm}$ was considered a tumor. Data represent mean $\pm \mathrm{SE}$ of 8 mice per group. (A) Tumor incidence and (B) tumor size, expressed as summation of tumor area (width $\mathrm{x}$ length in $\mathrm{mm}^{2}$ ) of palpable nodes per mouse are depicted. ${ }^{*} \mathrm{P}<0.05$ compared with PBS by Fischer's exact test (A), and Mann-Whitney U test (B).

mice induced marked tumor regression accompanying IFN- $\gamma$ production (Fig. 4C and D), consistent with a recent report showing tumor growth inhibition by IL-17 neutralization (15). Regardless of the pathway, Spirulina LPS inhibits tumor growth by skewing the balance between IFN- $\gamma$ and IL-17 responses toward IFN- $\gamma$ production.

In this study, Spirulina LPS was shown to inhibit the in vitro generation of IL-17-producing cells through its action on APCs in a TLR4-dependent manner (Fig. 4A and B). There are reports demonstrating that $\mathrm{CD} 86$, but not $\mathrm{CD} 80$, on APCs plays an important role in the regulation of IL-17 production by $\mathrm{T}$ cells (37), and that IL-27 produced by M $\phi / \mathrm{DC}$ negatively regulates the development of Th17 cells (38). Thus, Spirulina LPS-mediated TLR4 signaling may induce a change in APC status by modulating the expression patterns of co-stimulatory molecules and cytokines, leading to the attenuation of Th17 cell development. However, the precise mechanisms by which Spirulina LPS suppresses IL-17 and IL-23 remain to be elucidated.

In contrast to the tumor-promoting effects of the IL-17/IL-23 signaling axis, demonstrated in IL-17- or IL-23deficient mice, several groups have described that Th17 cells or IL-17 promote tumor inhibition by increasing the generation of tumor-specific cytotoxic CD8 T cells $(39,40)$. Thus, whether Th17 cells or IL-17 induce tumor progression or antitumor immunity might be dependent on the varied main effector cells in the distinct tumor-host relationship (41). Namely, Th17 cells/IL-17 could activate CD8 T cells, while inhibiting Th1 type of CD4 T cells. Otherwise, the strength of tumor immunogenicity or frequency of tumor-specific effector $\mathrm{T}$ cells might cause a discrepancy in the function of Th17 cells/IL-17, because adoptive transfer of tumor-reactive Th17 cells obtained from TCR transgenic mice or from in vitro stimulation with tumor inhibits tumor development $(39,40)$. In either case, IL-17-induced angiogenesis seems to be required to some extent for effector $\mathrm{T}$ cells to migrate into tumor tissue. Even in an IL-17-deficient host, IL-17 secreted by tumor cells may contribute to T-cell infiltration. Despite these possible explanations, the paradox in the function of Th17 cells/IL-17 is still unresolved.

IL-17 is also produced by certain tumors and IL-17 receptors have been detected in virtually all cells (12). It has been reported that IL-17 stimulates tumor cells to proliferate and upregulates the expression of various cytokines, chemokines, and their receptors, leading to angiogenesis (16,42-44). However, we did not detect expression of IL-17 and IL-17 receptor in MH134 tumor cells (data not shown), indicating the importance of IL-17 responses in host-derived cells in MH134 tumor growth. Moreover, although TLR4 was expressed on MH134 tumor cells, E. coli and Spirulina LPS had virtually no effect on the in vitro growth of tumor cells (data not shown). Interestingly, we found that MH134 tumor cells expressed IFN- $\gamma$ receptors and that cellular in vitro growth was inhibited by exogenous addition of IFN- $\gamma$ (data not shown). Thus, in vivo induction of IFN- $\gamma$ by E. coli and Spirulina LPS may partly contribute to the antitumor effects by virtue of the IFN- $\gamma$ direct action on the tumor.

E. coli LPS induced antitumor effects against a primary tumor, but failed to enhance secondary immune responses in the same tumor after reimplantation (Fig. 2A). E. coli LPS induced high levels of IL-6 and IL-23, favoring the development of Th17 cells, and it considerably activated NK function (Fig. 2B). Thus, it is conceivable that $E$. coli LPS inhibits primary tumor growth via activation of NK cells, but prevents the generation of $\mathrm{T}$ cell-mediated antitumor immunity through IL-17 induction.

The effects of E. coli and Spirulina LPS involve TLR4 pathways, but Spirulina LPS was different from E. coli LPS in terms of cytokine induction. The structure of LPS of all gramnegative bacteria consists of a polysaccharide attached to a lipid component, lipid A, which is assumed to be responsible for the induction of cytokines. Although lipid A molecules from different bacteria were initially thought to be similar, recent evidence suggests structural and functional differences among LPS from different species $(25,45)$. Differences in the three-dimensional conformation of lipid A have been proposed to determine the strength of fitness to TLR4CD14-MD2 complex, leading to the activation of intracellular signaling for cytokines $(46,47)$. LPS fractions from $E$. coli and Salmonella spp. are more potent cytokine inducers than those from Bordetella pertussis and Bacteroides fragilis $(48,49)$, while lipid A analog and LPS from Rhodobacter spp. have antagonistic properties against cytokine stimulation $(47,50)$. Although the structure of Spirulina LPS remains to be analyzed, the molecular conformation of E. coli LPS seems to be different from that of Spirulina LPS based on its ability to downregulate IL-17 with minimum induction of IL-6 and IL-23. Moreover, Spirulina LPS failed to induce endotoxin shock in contrast to E. coli LPS (20\% and $100 \%$ survival in mice given $25 \mu \mathrm{g}$ of E. coli and Spirulina LPS, respectively, $36 \mathrm{~h}$ after administration).

Experiments using different Spirulina preparations free of LPS have demonstrated antitumor activity. A calciumchelating, sulfated polysaccharide from S. platensis suppressed 
metastasis of murine melanoma (51). Oral administration of hot water extract of Spirulina is reported to suppress tumor growth through IFN- $\gamma$-mediated activation of NK cells but not CD8 T cells (52). However, it was not clear whether IL-17 and IL-23 production were involved in the experimental system of that specific study. In contrast to those Spirulina preparations, we used a Spirulina LPS fraction extracted with phenol-water. Differences in the components of the Spirulina extracts may cause distinct bioactivities.

In conclusion, Spirulina LPS suppressed tumor growth by downregulating serum IL-17/IL-23 with concomitant induction of IFN- $\gamma$ through TLR4. Furthermore, Spirulina LPS showed limited or no induction of IL-6 and IL-23 and altered the cytokine milieu in the tumor-bearing host from the Th17 to the Th1 type. Thus, we confirmed the importance of a balance between IFN- $\gamma$ and IL-17/IL-23 levels in the regulation of tumor growth. It is noteworthy that Spirulina LPS was able to suppress spontaneous development of mammary tumors. Our results provide novel insights into the exploitation of TLR-based immunomodulators for cancer immunotherapy.

\section{Acknowledgements}

This study was supported by The Osaka Foundation of Promotion for Clinical Immunology (S.O. and Y K.) and JSPS Grant-in-Aid for Scientific Research \#21550168 (S.F.). We would like to thank Dr G. Cysewski (Cyanotech Corporation, Hawaii) and Mr. N. Miyaji (Toyo Koso Kagaku Co., Ltd., Japan) for providing Spirulina pacifica.

\section{References}

1. Sylvester RJ, van der Meijden AP, Witjes JA and Kurth K Bacillus calmette-guerin versus chemotherapy for the intravesical treatment of patients with carcinoma in situ of the bladder: A meta-analysis of the published results of randomized clinical trials. J Urol 174: 86-91, discussion 91-92, 2005.

2. Medzhitov R and Janeway CA Jr: Innate immunity: The virtues of a nonclonal system of recognition. Cell 91: 295-298, 1997.

3. Akira S, Takeda K and Kaisho T: Toll-like receptors: Critical proteins linking innate and acquired immunity. Nat Immunol 2: 675-680, 2001.

4. Trinchieri G: Interleukin-12 and the regulation of innate resistance and adaptive immunity. Nat Rev Immunol 3: 133-146, 2003.

5. Dalton DK, Pitts-Meek S, Keshav S, Figari IS, Bradley A and Stewart TA: Multiple defects of immune cell function in mice with disrupted interferon- $\gamma$ genes. Science 259: 1739-1742, 1993.

6. Shankaran V, Ikeda H, Bruce AT, White JM, Swanson PE, Old LJ and Schreiber RD: IFNgamma and lymphocytes prevent primary tumour development and shape tumour immunogenicity. Nature 410: 1107-1111, 2001.

7. Dighe AS, Richards E, Old LJ and Schreiber RD: Enhanced in vivo growth and resistance to rejection of tumor cells expressing dominant negative IFN $\gamma$ receptors. Immunity 1: 447-456, 1994.

8. Mizuno D, Yoshioka O, Akamatu M and Kataoka T: Antitumor effect of intracutaneous injection of bacterial lipopolysaccharide. Cancer Res 28: 1531-1537, 1968.

9. Ohnishi M, Kimura S, Yamazaki M, Oshima H, Mizuno DI, Abe $\mathrm{S}$ and Yamaguchi H: Anti-tumour activity of low-toxicity lipopolysaccharide of Bordetella pertussis. Br J Cancer 69: 1038-1042, 1994.

10. Yang D, Satoh M, Ueda H, Tsukagoshi S and Yamazaki M: Activation of tumor-infiltrating macrophages by a synthetic lipid A analog (ONO-4007) and its implication in antitumor effects. Cancer Immunol Immunother 38: 287-293, 1994.

11. Tartour E, Fossiez F, Joyeux I, Galinha A, Gey A, Claret E, SastreGarau X, Couturier J, Mosseri V, Vives V, et al: Interleukin 17, a T-cell-derived cytokine, promotes tumorigenicity of human cervical tumors in nude mice. Cancer Res 59: 3698-3704, 1999.
12. Kato T, Furumoto H, Ogura T, Onishi Y, Irahara M, Yamano S, Kamada M and Aono T: Expression of IL-17 mRNA in ovarian cancer. Biochem Biophys Res Commun 282: 735-738, 2001.

13. Numasaki M, Watanabe M, Suzuki T, Takahashi H, Nakamura A, McAllister F, Hishinuma T, Goto J, Lotze MT, Kolls JK, et al: IL-17 enhances the net angiogenic activity and in vivo growth of human non-small cell lung cancer in SCID mice through promoting CXCR-2-dependent angiogenesis. J Immunol 175: 6177-6189, 2005

14. Langowski JL, Zhang X, Wu L, Mattson JD, Chen T, Smith K, Basham B, McClanahan T, Kastelein RA and Oft M: IL-23 promotes tumour incidence and growth. Nature 442: 461-465, 2006.

15. He D, Li H, Yusuf N, Elmets CA, Li J, Mountz JD and Xu H: IL-17 promotes tumor development through the induction of tumor promoting microenvironments at tumor sites and myeloidderived suppressor cells. J Immunol 184: 2281-2288, 2010.

16. Wang L, Yi T, Kortylewski M, Pardoll DM, Zeng D and Yu H: IL-17 can promote tumor growth through an IL-6-Stat3 signaling pathway. J Exp Med 206: 1457-1464, 2009.

17. Kortylewski M, Xin H, Kujawski M, Lee H, Liu Y, Harris T, Drake C, Pardoll D and Yu H: Regulation of the IL-23 and IL-12 balance by Stat 3 signaling in the tumor microenvironment. Cancer Cell 15: 114-123, 2009.

18. Kastelein RA, Hunter CA and Cua DJ: Discovery and biology of IL-23 and IL-27: Related but functionally distinct regulators of inflammation. Annu Rev Immunol 25: 221-242, 2007.

19. Korn T, Bettelli E, Oukka M and Kuchroo VK: IL-17 and Th17 Cells. Annu Rev Immunol 27: 485-517, 2009.

20. Bettelli E, Carrier Y, Gao W, Korn T, Strom TB, Oukka M, Weiner HL and Kuchroo VK: Reciprocal developmental pathways for the generation of pathogenic effector TH17 and regulatory T cells. Nature 441: 235-238, 2006.

21. Goriely S, Neurath MF and Goldman M: How microorganisms tip the balance between interleukin- 12 family members. Nat Rev Immunol 8: 81-86, 2008.

22. Kelly MG, Alvero AB, Chen R, Silasi DA, Abrahams VM, Chan S, Visintin I, Rutherford T and Mor G: TLR-4 signaling promotes tumor growth and paclitaxel chemoresistance in ovarian cancer. Cancer Res 66: 3859-3868, 2006.

23. Yu H, Kortylewski M and Pardoll D: Crosstalk between cancer and immune cells: Role of STAT3 in the tumour microenvironment. Nat Rev Immunol 7: 41-51, 2007.

24. Tominaga A, Okuyama H, Fukuoka S, Taguchi T, Kusumoto Y, Shimizu K and Ono S: Effects of edible algae polysaccharides on allergic, inflammatory, and anti-tumor responses through toll-like receptor 4. Antiinflamm Antiallergy Agents Med Chem 9: 238-250, 2010.

25. Stewart I, Schluter PJ and Shaw GR: Cyanobacterial lipopolysaccharides and human health - a review. Environ Health 5: 7-29, 2006.

26. Tornabene TG, Bourne TF, Raziuddin S and Ben-Amotz A: Lipid and lipopolysaccharide constituents of cyanobacterium Spirulina platensis (Cyanophyceae, Nostocales). Mar Ecol Prog Ser 22: 121-125, 1985.

27. Westphal O and Jann K: Bacterial lipopolysaccharides. Extraction with phenol-water and further applications of the procedure. In: Methods in Carbohydrate Chemistry. Whistler RL and Wolfan ML (eds). Academic Press Inc., New York, pp83-91, 1965.

28. Takeuchi N, Hiraoka S, Zhou XY, Nagafuku M, Ono S, Tsujimura T, Nakazawa M, Yura Y, Hamaoka T and Fujiwara H: Anti-HER-2/neu immune responses are induced before the development of clinical tumors but declined following tumorigenesis in HER-2/neu transgenic mice. Cancer Res 64: 7588-7595, 2004.

29. Zou JP, Shimizu J, Ikegame K, Yamamoto N, Ono S, Fujiwara H and Hamaoka T: Tumor-bearing mice exhibit a progressive increase in tumor antigen-presenting cell function and a reciprocal decrease in tumor antigen-responsive $\mathrm{CD}^{+} \mathrm{T}$ cell activity. J Immunol 148: 648-655, 1992.

30. Poltorak A, He X, Smirnova I, Liu MY, Van Huffel C, Du X, Birdwell D, Alejos E, Silva M, Galanos C, et al: Defective LPS signaling in $\mathrm{C} 3 \mathrm{H} / \mathrm{HeJ}$ and $\mathrm{C} 57 \mathrm{BL} / 10 \mathrm{ScCr}$ mice: Mutations in Tlr4 gene. Science 282: 2085-2088, 1998.

31. Yamamoto N, Zou JP, Li XF, Takenaka H, Noda S, Fujii T, Ono S, Kobayashi Y, Mukaida N, Matsushima K, et al: Regulatory mechanisms for production of IFN- $\gamma$ and TNF by antitumor $\mathrm{T}$ cells or macrophages in the tumor-bearing state. J Immunol 154: 2281-2290, 1995.

32. Park H, Li Z, Yang XO, Chang SH, Nurieva R, Wang YH, Wang Y, Hood L, Zhu Z, Tian Q, et al: A distinct lineage of CD4 T cells regulates tissue inflammation by producing interleukin 17 . Nat Immunol 6: 1133-1141, 2005. 
33. Harrington LE, Hatton RD, Mangan PR, Turner H, Murphy TL, Murphy KM and Weaver CT: Interleukin 17-producing CD4 ${ }^{+}$ effector T cells develop via a lineage distinct from the T helper type 1 and 2 lineages. Nat Immunol 6: 1123-1132, 2005.

34. Nakajima C, Uekusa Y, Iwasaki M, Yamaguchi N, Mukai T, Gao P, Tomura M, Ono S, Tsujimura T, Fujiwara H, et al: A role of interferon- $\gamma(\mathrm{IFN}-\gamma)$ in tumor immunity: T cells with the capacity to reject tumor cells are generated but fail to migrate to tumor sites in IFN- $\gamma$-deficient mice. Cancer Res 61: 3399-3405, 2001.

35. O'Connor W Jr, Kamanaka M, Booth CJ, Town T, Nakae S, Iwakura Y, Kolls JK and Flavell RA: A protective function for interleukin 17A in T cell-mediated intestinal inflammation. Nat Immunol 10: 603-609, 2009.

36. Kawanishi Y, Tominaga A, Okuyama H, Fukuoka S, Taguchi T, Kusumoto Y, Yawata T, Fujimoto Y, Ono S and Shimizu K: Regulatory effects of Spirulina complex polysaccharides on growth of murine RSV-M glioma cells through Toll-like receptor 4. Microbiol Immunol 57: 63-73, 2013.

37. Odobasic D, Leech MT, Xue JR and Holdsworth SR: Distinct in vivo roles of CD80 and CD86 in the effector T-cell responses inducing antigen-induced arthritis. Immunology 124: 503-513, 2008.

38. Stumhofer JS, Laurence A, Wilson EH, Huang E, Tato CM, Johnson LM, Villarino AV, Huang Q, Yoshimura A, Sehy D, et al: Interleukin 27 negatively regulates the development of interleukin 17-producing $\mathrm{T}$ helper cells during chronic inflammation of the central nervous system. Nat Immunol 7: 937-945, 2006.

39. Martin-Orozco N, Muranski P, Chung Y, Yang XO, Yamazaki T, Lu S, Hwu P, Restifo NP, Overwijk WW and Dong C: T helper 17 cells promote cytotoxic $\mathrm{T}$ cell activation in tumor immunity. Immunity 31: 787-798, 2009.

40. Muranski P, Boni A, Antony PA, Cassard L, Irvine KR, Kaiser A, Paulos CM, Palmer DC, Touloukian CE, Ptak K, et al: Tumor-specific Th17-polarized cells eradicate large established melanoma. Blood 112: 362-373, 2008

41. Murugaiyan G and Saha B: Protumor vs. antitumor functions of IL-17. J Immunol 183: 4169-4175, 2009.

42. Yao Z, Fanslow WC, Seldin MF, Rousseau AM, Painter SL Comeau MR, Cohen JI and Spriggs MK: Herpesvirus Saimiri encodes a new cytokine, IL-17, which binds to a novel cytokine receptor. Immunity 3: 811-821, 1995.
43. Kolls JK and Lindén A: Interleukin-17 family members and inflammation. Immunity 21: 467-476, 2004.

44. Cirée A, Michel L, Camilleri-Bröet S, Jean Louis F, Oster M, Flageul B, Senet P, Fossiez F, Fridman WH, Bachelez H, et al: Expression and activity of IL-17 in cutaneous T-cell lymphomas (mycosis fungoides and Sezary syndrome). Int J Cancer 112: 113-120, 2004.

45. Netea MG, van Deuren M, Kullberg BJ, Cavaillon JM and Van der Meer JW: Does the shape of lipid A determine the interaction of LPS with Toll-like receptors? Trends Immunol 23: 135-139, 2002.

46. Miller SI, Ernst RK and Bader MW: LPS, TLR4 and infectious disease diversity. Nat Rev Microbiol 3: 36-46, 2005.

47. Schromm AB, Brandenburg K, Loppnow H, Moran AP, Koch MH, Rietschel ET and Seydel U: Biological activities of lipopolysaccharides are determined by the shape of their lipid A portion. Eur J Biochem 267: 2008-2013, 2000.

48. Lebbar S, Cavaillon JM, Caroff M, Ledur A, Brade H, Sarfati R and Haeffner-Cavaillon N: Molecular requirement for interleukin 1 induction by lipopolysaccharide-stimulated human monocytes: Involvement of the heptosyl-2-keto-3-deoxyoctulosonate region. Eur J Immunol 16: 87-91, 1986.

49. Gangloff SC, Hijiya N, Haziot A and Goyert SM: Lipopolysaccharide structure influences the macrophage response via CD14-independent and CD14-dependent pathways. Clin Infect Dis 28: 491-496, 1999.

50. Loppnow H, Libby P, Freudenberg M, Krauss JH, Weckesser J and Mayer H: Cytokine induction by lipopolysaccharide (LPS) corresponds to lethal toxicity and is inhibited by nontoxic Rhodobacter capsulatus LPS. Infect Immun 58: 3743-3750, 1990.

51. Mishima T, Murata J, Toyoshima M, Fujii H, Nakajima M Hayashi T, Kato T and Saiki I: Inhibition of tumor invasion and metastasis by calcium spirulan (Ca-SP), a novel sulfated polysaccharide derived from a blue-green alga, Spirulina platensis. Clin Exp Metastasis 16: 541-550, 1998.

52. Akao Y, Ebihara T, Masuda H, Saeki Y, Akazawa T, Hazeki K, Hazeki O, Matsumoto M and Seya T: Enhancement of antitumor natural killer cell activation by orally administered Spirulina extract in mice. Cancer Sci 100: 1494-1501, 2009. 